\title{
Effect of Exogenous Phytase on the Phosphorus Balance of Lactating Cows Fed A Corn Based Diet
}

\author{
Laura Winter \\ Institute of Animal Nutrition, Friedrich-Loeffler-Institute (FLI) \\ Federal Research Institute for Animal Health, Braunschweig, Germany \\ Tel: 49-531-596-3151 E-mail: laura.winter@fli.bund.de
}

Ulrich Meyer (Corresponding author)

Institute of Animal Nutrition, Friedrich-Loeffler-Institute (FLI)

Federal Research Institute for Animal Health, Braunschweig, Germany

Tel: 49-531-596-3137Ｅ-mail: Ulrich.meyer@ fli.bund.de

\begin{abstract}
Markus Spolders
Federal Institute for Risk Assessment, Health Assessment of Feeds

Max-Dohrn-Str. 8-10, 10589 Berlin-Jungfernheide, Germany

E-mail: markus.spolders@bfr.bund.de
\end{abstract}

Liane Hüther

Institute of Animal Nutrition, Friedrich-Loeffler-Institute (FLI)

Federal Research Institute for Animal Health, Braunschweig, Germany

Tel: 49-531-596-3128Ｅ-mail: Liane.huether@ fli.bund.de

Peter Lebzien

Institute of Animal Nutrition, Friedrich-Loeffler-Institute (FLI)

Federal Research Institute for Animal Health, Braunschweig, Germany

E-mail: Peter.lebzien@fli.bund.de 
Sven Dänicke

Institute of Animal Nutrition, Friedrich-Loeffler-Institute (FLI)

Federal Research Institute for Animal Health, Braunschweig, Germany

Tel: 49- 531-596-01Ｅ-mail: Sven.daenicke@ fli.bund.de

Received: May 16, 2013 Accepted: May 30, 2013

doi:10.5296/jbls.v4i2.3697 URL: http://dx.doi.org/10.5296/jbls.v4i2.3697

\begin{abstract}
The present study investigated the effect of $\mathrm{P}$ or phytase supplementation on the P-balance of dairy cows. 24 lactating German Holstein cows were used for a 5-weeks feeding trial and were allocated to three dietary treatments, P+MIN, P-MIN and P+PHY. All cows received a total mixed ration (TMR) composed of $63 \%$ corn silage and $37 \%$ concentrate on a dry matter (DM) basis for ad libitum intake. The concentrate of the P+MIN group was supplemented with dicalcium phosphate and represents the control group. The concentrate of the P-MIN group was unsupplemented and the concentrate of the $\mathrm{P}+\mathrm{PHY}$ group was supplemented with an exogenous phytase $(0.1 \mathrm{~g} / \mathrm{kg}$ DM in the TMR; $50000 \mathrm{FTU} / \mathrm{g})$. The $\mathrm{P}$ concentration in the TMR of the P+MIN, P-MIN and P+PHY groups were 3.98, 3.46 and $3.26 \mathrm{~g} \mathrm{P} / \mathrm{kg} \mathrm{DM}$, respectively.

Dry matter intake (DMI) and milk yield were recorded daily. In the last two weeks samples of milk, urine and blood were collected. Samples of faeces were collected to determine the P-balances by using the acid insoluble ash (AIA) marker technique.

No differences in P-concentration of milk, urine and faeces were observed between the treatments. The P-digestibility of Group P+MIN and P-MIN was 60 and 56\%, respectively. These values were not different compared to the P-digestibility of 57\% in the P+PHY-group. The P-balance in the P+MIN group (26 g/d) was higher compared to the P-MIN (16g/d) and $\mathrm{P}+\mathrm{PHY}(17 \mathrm{~g} / \mathrm{d})$ treatment. Overall, phytase supplementation had no effect on P-digestibility and P-balance of dairy cows in this trial.
\end{abstract}

Keywords: Phytase, Ruminants, P-digestibility, P-balance

\title{
1. Introduction
}

In the past, dairy cows were often fed diets containing $\mathrm{P}$ levels markedly higher than the recommendations for $\mathrm{P}$ supply. The most common explanation for this oversupply is the perception that high-P diets improve reproductive performance. In addition, the recommendations for adequate $\mathrm{P}$ supply differ from nation to nation (CVB, 2005; GfE, 2001; INRA, 2002; NRC, 2001; Schlegel, 2011). Consequential the proportion of excreted P, which is not used to meet the requirements of the cow, increases. Moreover, natural P sources used as mineral feedstuffs become more and more limited in the future (Rodehutscord, 2008). 


\section{Mll Macrothink}

Journal of Biology and Life Science ISSN 2157-6076 2013, Vol. 4, No. 2

Therefore, it remains a challenge for animal nutrition to reduce the dietary $\mathrm{P}$ supply while meeting the requirement at the same time. One way to increase the P-absorption and to reduce faecal P is the supply of exogenous phytase to the diets (Knowlton et al., 2007). The enzyme phytase has a relevant impact in the reduction of P-excretion by excrements from monogastrics. Due to its ability to cleave phosphate from its binding to the inositol ring, phytase supply more P for absorption in the small intestine (Guyton et al., 2003). In ruminants, phytase is secreted intracellular by ruminal bacteria (Yanke et al., 1998) and phytate hydrolysis also occurs in the lower gastrointestinal tract (small intestine with duodenum, jejunum, ileum) of ruminants. Thus the total tract hydrolysis of phytate is nearly complete (Brask-Pedersen et al., 2013). However, for $\mathrm{P}$ to be absorbed from the small intestine, the phytate hydrolysis must occur in the rumen. Using in vitro ruminal techniques Morse et al. (1992) and Brask-Pedersen et al. (2011) found out that the effect of exogenous phytase is closely related to the composition of the feedstuff, the $\mathrm{pH}$-value level, the kind of phytase and the time of incubation. Additionally, Brask-Pedersen et al. (2011) observed that the supply of exogenous phytase in vitro can influence the P-utilization positively. These results are sustained by Garikipati and Kincaid (2004), who figured out a positive effect of the influence of exogenous phytase in dairy cows. However, data regarding the intake of $\mathrm{P}$ and the use of exogenous phytase are inadequate. Kincaid et al. (2005) tested the effects of grain source and exogenous phytase supplementation on the digestibility of $\mathrm{P}$ and concluded that exogenous phytase could have an influence on the faecal P-excretion of dairy cows. Although the main part of phytase activity in the rumen is of bacterial origin (Yanke et al., 1998), phytin hydrolysis might also be caused by intrinsic phytase contained in the diet, whereby however only some cereals and their by-products show phytase activities of more than 100 units/kg (Eeckhout \& De Paepe, 1994). The phytase activity in corn is below the detection limit (Zimmermann et al., 2002). According to current knowledge, there is no certain way to identify the quantitative influence of plant phytase on ruminal phytate hydrolysis (Kincaid \& Rodehutscord, 2005). Experiments in a semi-continuous culture system by Godoy and Meschy (1999) with P of inorganic and organic origin suggest that in some situations the ruminal phytase activity does not hydrolyze all dietary phytate. Time of incubation of feed in the gastro intestinal tract is getting shorter in high lactating cows, because the feed intake increases with the increasing performance. Based on this, the passage rate increases and with this the time of P-hydrolyses gets even lower (Garikipati \& Kincaid, 2004).

Overall, these observed effects of phytase could influence the P-balance of dairy cows and previous studies (Kincaid et al., 2005; Knowlton et al., 2007) comprise no complete P-balances. In addition the interaction between inorganic phosphorus $\left(\mathrm{P}_{\mathrm{i}}\right)$ in serum and P-excretion via urine and milk remained unconsidered. Due to the limited quantity of studies to the supply of exogenous phytase in vivo, the aim of the present study was to determine a P-balance of lactating cows fed a corn based diet with a commonly used P-concentration, to ascertain further indicators for the effects of exogenous phytase and to study the impact on the concentration of $\mathrm{P}$ in milk, urine, faeces and blood. 


\section{Materials and Methods}

\subsection{Animals, Treatments and Experimental Design}

The experiment was carried out with 24 lactating pluriparous German Holstein cows at the experimental station of the Institute of Animal Nutrition, Friedrich-Loeffler-Institute (FLI), Federal Research Institute for Animal Health, in Braunschweig, Germany. At the beginning of the trial, the cows had an average milk yield of $26.8 \pm 1.9 \mathrm{~kg} / \mathrm{d}$ and a mean body weight of 648 $\pm 64 \mathrm{~kg}$. The mean lactation day was $196 \pm 26$ and the animals were, on average, in their $2.8 \pm$ 1.0 lactation. The animals were randomly assigned to one of three feeding groups, with eight cows each, based on milk yield, body weight, days in lactation and the number of lactation. The cows were kept in a free stall barn with a slatted floor and cubicles.

The animals were fed ad libitum with corn silage and concentrate as a TMR, with $37 \%$ concentrate and $63 \%$ corn silage (on a DM basis). The concentrates were added in pelleted form to the corn silage and mixed in a feed mixer just before feeding. The diets were intended to cover the demand of energy and protein according to the recommendations of the Society of Nutrition Physiology (GfE, 2001).

Three experimental diets were fed. Mineral $\mathrm{P}$ is supplied to the $\mathrm{P}+\mathrm{MIN}$ diet. The diet represents the commonly used P-concentration for dairy cows with a milk yield of approximately $30 \mathrm{~kg} / \mathrm{d}$ and a feed intake of about $20 \mathrm{~kg} \mathrm{DM} / \mathrm{d}$. The TMR of group P-MIN included the native $\mathrm{P}$ of the feedstuffs without $\mathrm{P}$-supplementation. The animals of group $\mathrm{P}+\mathrm{PHY}$ got the same concentrate as group P-MIN e.g. Table 1, but supplemented with an experimental phytase $(0.1 \mathrm{~g} / \mathrm{kg}$ DM in the TMR). The phytase had an activity of min. 50000 FTU/g according to the manufacturer's specifications (Experimental Phytase, manufacturer DSM-Nutritional Products Ltd, Basel, Switzerland). Determination of phytase activity in the feedstuff followed the procedure of Engelen et al. (1994). Phytase activity was determined in rumen samples and expressed in FTU adapted from the definition of Engelen et al. (1994).

Table 1. Composition of the concentrates used during the trial

\begin{tabular}{|l|c|c|c|}
\hline & Concentrate 1 (\%) & Concentrate 2 (\%) & Concentrate 3 (\%) \\
\hline Corn & 40.0 & 40.0 & 40.0 \\
\hline Soybean meal & 35.0 & 35.0 & 35.0 \\
\hline Dried sugar beet pulp & 19.7 & 20.0 & 20.0 \\
\hline Calcium carbonate & 0.7 & 1.3 & 1.3 \\
\hline Urea & 1.5 & 1.5 & 1.5 \\
\hline Sodium chloride & 0.2 & 0.2 & 0.2 \\
\hline Mineral premix & 2.0 & 2.0 & - \\
\hline Mineral premix with phytase $^{\dagger}$ & - & - & 2.0 \\
\hline Dicalcium phosphate & 0.9 & - & - \\
\hline
\end{tabular}

* Composition (per kg): 200g calcium, 120g sodium, 40g magnesium, 1000000 IU vitamin A (E672), 100000 IU vitamin D3 (E671), $1500 \mathrm{mg}$ vitamin E (alpha Tocopherolacetat), $5400 \mathrm{mg}$ Mangan (Mangan (II)sulfat, Monohydrat E5), $6000 \mathrm{mg}$ Zinc (Zincoxide E6), $1000 \mathrm{mg}$ copper (copper sulfate pentahydrate E4), $100 \mathrm{mg}$ iod 
(calcium jodate, waterfree E2), $40 \mathrm{mg}$ selenium (Sodium Selenate E8), $25 \mathrm{mg}$ cobalt (cobalt sulfate, monohydrate, E3)

${ }^{\dagger}$ Composition (per kg): see premix ${ }^{1}$ added with 14.8 g phytase (phytase activity amounted to 50000 FTU**/g)

**FTU: one FTU is the amount of enzymes that liberates $1 \mu$ mol of inorganic P per minute from an excess of Na phytate at $\mathrm{pH} 5.5$ and $37^{\circ} \mathrm{C}$ (Engelen et al., 1994)

\subsection{Measurements and Sampling Procedure}

Individual feed and water intake were recorded continuously by an automatic feeding system (manufacturer Insentec B.V., Marknesse, The Netherlands). The first three weeks of the trial were conducted as an adaptation period, followed by a two- week sampling period.

During the sampling period, representative samples of the diet were collected daily. After collection, the samples were stored at $-18^{\circ} \mathrm{C}$ and pooled to one sample.

Cows were milked twice daily at 05:30 am and 03:30 pm in a milking parlour (manufacturer Lemmer-Fullwood, Lohmar, Germany). The milk yield was recorded automatically. Twice a week milk samples were taken during morning and afternoon milking to determine fat, protein, lactose, urea and somatic cell count (SCC). The samples were conserved with bronopol and stored at $8^{\circ} \mathrm{C}$ until analysis. Individual body weight was determined twice daily after milking.

Blood samples were collected to prove that only cows in good metabolic condition were included in the study. The blood samples were taken for analysis of clinical blood parameters at day 0 of the adaptation period and at the end of the trial. Additionally, samples of blood, urine, faeces and milk were taken for P- and Ca-analysis from every cow on day 1, 3, 5, 8, 10 and 12 during the last two weeks of the experiment. That means that during the sampling period, blood was collected six times in serum tubes from a vena jugularis externa. Approximately one hour after sampling, serum was separated by centrifugation at $3000 \mathrm{x}$ g for 30 minutes at $15^{\circ} \mathrm{C}$. The serum was filled into tubes and stored at $-18^{\circ} \mathrm{C}$ until analysis of clinical blood parameters.

\subsection{Analyses}

Samples of feedstuff and faeces were analyzed for DM, ash, crude protein (CP), crude fibre (CF) and ether extract (EE) according to the methods of the Verband Deutscher Landwirtschaftlicher Untersuchungs- und Forschungsanstalten (VDLUFA, 1997). Feedstuff samples were dried at $60^{\circ} \mathrm{C}$ for 72 hours and ground through a 1-mm screen. Analysis of acid and neutral detergent fibre (ADF resp. NDF) was conducted following the methods of VDLUFA (1997). Samples of morning and evening milk were pooled according to their milk yields and freeze dried for analysis of $\mathrm{Ca}$ and $\mathrm{P}$. Faeces samples were taken during the last two experimental weeks and freeze dried for the determination of nutrients and acid AIA.

$\mathrm{Ca}$ and $\mathrm{P}$ in TMR, milk, urine and faeces were analyzed by an optical emissions spectrometer with inductively coupled plasma (ICP-OES) according to VDLUFA (1997).

The phytase content of the concentrates is determined via the phytase activity and expressed as units $(\mathrm{U}) / \mathrm{kg}$ feed. The analytical method is based on the method of the draft of the Comite 


\section{Al Macrothink}

Journal of Biology and Life Science

ISSN 2157-6076

2013, Vol. 4, No. 2

Europeen de Normalisation (CEN) standard (12) which is published as ISO 30024 (Gizzi et al., 2008).

The milk samples were analyzed for fat, protein, lactose, urea and SCC with a Fourier transform infrared spectroscopy and flow cytometric measurement system (Milkoscan FT 6000 combined with a Fossomatic 5000, Foss Electric, Hillerød, Denmark).

Measurements of AIA are suited to predict the digestibility in ruminants (Sunvold \& Cochran, 1991). The AIA in feed and faeces was analyzed with the 4N HCl-method. This is an adapted form of the method described by Wünsche et al. (1984) and Mccarthy et al. (1974). A total of 2 to $5 \mathrm{~g}$ of freeze dried faeces or feed were ashed. The ignition of the samples lasted 5 hours at a temperature of $550^{\circ} \mathrm{C}$. The ashes were boiled for 15 minutes with $4 \mathrm{~N} \mathrm{HCl}$ and the residues were filtered with an ashless filter paper. After drying the filters with the residues, they were ashed again to obtain the amount of AIA. The nutrient concentration in faeces samples was analyzed in the same way as in the feed. The concentration of $\mathrm{P}, \mathrm{Ca}$ and different clinical chemical parameters like total protein, aspartate aminotransferase (AST), gamma glutamyltransferase (GGT), glutamate dehydrogenase (GLDH), cholesterine, glucose, free fatty acids (FFA), B-hxdroxybutyrate, urea and creatinine were analyzed in blood serum samples. The analysis of the clinical chemical parameters was carried out using a Cobas Mira Plus Chemistry Analyzer (Hoffmann-La Roche Ltd., Basel, Switzerland).

Inositol-P (InsP-6/5/4/3/2/1) was analyzed in all samples using high-performance ion chromatography according to the method of Brejnholt et al. (2011). The majority of total P was present as phytate P. Phytate $\mathrm{P}$ was determined by a standard 'ferric chloride precipitation`-method (Selle et al., 2003).

\subsection{Calculations}

The apparent total tract digestibility (AD) of organic matter (OM), CF, EE, P and Ca was estimated by AIA as a marker occurring naturally in the diet. The results of AIA and OM, CF, $\mathrm{EE}, \mathrm{P}$ and $\mathrm{Ca}$ analysis from the different diets and faeces were used to calculate the $\mathrm{AD}$ of $\mathrm{OM}$, $\mathrm{CF}, \mathrm{EE}$ as well as $\mathrm{Ca}$ and $\mathrm{P}$ as follows:

$\mathrm{AD}[\%]=\left(\left[\left(\mathrm{N}_{\text {diet }} / \mathrm{AIA}_{\text {diet }}\right)-\left(\mathrm{N}_{\text {faeces }} / \mathrm{AIA}_{\text {faeces }}\right)\right] / \mathrm{N}_{\text {diet }} / \mathrm{AIA}_{\text {diet }}\right) * 100$,

where $\mathrm{N}_{\text {diet }}$ is the nutrient concentration $(\mathrm{OM}, \mathrm{CF}, \mathrm{EE}, \mathrm{P}, \mathrm{Ca})$ in $\mathrm{g} / \mathrm{kg} \mathrm{DM}$ and $\mathrm{AIA}_{\text {diet }}$ is the AIA concentration in $\mathrm{g} / \mathrm{kg}$ DM in the feed. $\mathrm{N}_{\text {faeces }}$ is the nutrient concentration (OM, CF, CL, $\mathrm{P}$, $\mathrm{Ca}$ in $\mathrm{g} / \mathrm{kg} \mathrm{DM})$ and $\mathrm{AIA}_{\text {faeces }}$ the AIA concentration $(\mathrm{g} / \mathrm{kg} \mathrm{DM})$ in faeces.

The ME content was calculated according to GfE (2001) by using the digestibilities from the AIA method:

$\mathrm{ME}[\mathrm{MJ}]=0.0312 \times \mathrm{g} \mathrm{DEE}+0.0136 \mathrm{x} \mathrm{g} \mathrm{DCF}+0.0147 \times \mathrm{g}(\mathrm{DOM}-\mathrm{DEE}-\mathrm{DCF})+0.00234 \mathrm{x}$ $\mathrm{g} \mathrm{CP}$

Where $\mathrm{CP}$ is crude protein, DEE is digestible ether extract; DCF digestible crude fibre and DOM digestible OM. 
P-excretion with urine was calculated as:

P-excretion in urine $[\mathrm{g} / \mathrm{d}]=\mathrm{P}$-concentration in urine $[\mathrm{g} / \mathrm{mL}] * 40[\mathrm{~mL} / \mathrm{kg} / \mathrm{d}] * \mathrm{BW}[\mathrm{kg}]$.

According to Kienzle (1991) it is assumed that the mean urine excretion of dairy cows is 40 $\mathrm{mL} / \mathrm{kg}$ body weight (BW) per day.

P-balance was calculated with the following equitation:

Balance $[\mathrm{g} / \mathrm{d}]=\mathrm{P}$-intake $[\mathrm{g} / \mathrm{d}]$ - faecal P $[\mathrm{g} / \mathrm{d}]$ - urinary P $[\mathrm{g} / \mathrm{d}]-$ milk P $[\mathrm{g} / \mathrm{d}]$.

The phytase activity for the corn silage is calculated according to tabulated values of Eeckhout and De Paepe (1994). This results in a phytase activity for corn silage of 12 FTU/kg DM.

\subsection{Statistical Analysis}

The statistical analysis was carried out with the SAS-software package Version 9.1.3 (SAS Institute, Cary, NC, USA 2004).

The procedure "MIXED" with a compound symmetry covariance was used to analyse the data. The treatment group was assumed to be the fixed effect. The fact that each cow was used for frequent measurements was considered using a "REPEATED" statement for the individual animal effect. The "PDIFF" option was used to determine significant effects between the least square means and "TUKEY-KRAMER" test was applied for post-hoc analysis. The results of the trial are presented as least squares means (LS means) \pm standard error of the mean (SE). Effects are graded as significant with $\mathrm{P}<0.05$.

\section{Results}

\subsection{Chemical Composition of the Feedstuffs}

The mean nutrient and energy content of the diets is shown in e.g. Table 2. All three experimental groups received a TMR with an average energy content of $11.4 \mathrm{MJ} \mathrm{ME} / \mathrm{kg} \mathrm{DM}$ and 7.0 MJ NEL/kg DM. P-concentrations in the TMR were 3.98, 3.46, and $3.26 \mathrm{~g} / \mathrm{kg} \mathrm{DM}$ in groups $\mathrm{P}+\mathrm{MIN}, \mathrm{P}-\mathrm{MIN}$ and $\mathrm{P}+\mathrm{PHY}$, respectively. The concentration of phytate $\mathrm{P}$ in total $\mathrm{P}$ of the different diets is listed in e.g. Table 2. The proportion of phytate $\mathrm{P}$ was between 58.5 and $69.9 \%$ of the total P-concentration in the diets.

Table 2. Chemical composition of the total mixed rations (TMR) in the experimental groups (g/kg DM)

\begin{tabular}{|l|c|c|c|}
\hline & $\begin{array}{c}\text { TMR 1 } \\
\text { P+MIN }^{1}\end{array}$ & $\begin{array}{c}\text { TMR 2 } \\
\text { P-MIN }^{2}\end{array}$ & $\begin{array}{c}\text { TMR 3 } \\
\text { P+PHY }^{3}\end{array}$ \\
\hline \multicolumn{4}{|c|}{$(\mathrm{g} / \mathrm{kg} \mathrm{DM})$} \\
\hline Organic matter & 947 & 943 & 945 \\
\hline Crude protein & 137 & 151 & 152 \\
\hline Ether extract & 24 & 35 & 28 \\
\hline
\end{tabular}




\begin{tabular}{|l|c|c|c|}
\hline Crude fibre & 152 & 158 & 153 \\
\hline ADF & 164 & 178 & 172 \\
\hline $\mathrm{NDF}$ & 346 & 376 & 358 \\
\hline $\mathrm{P}$ & 3.98 & 3.46 & 3.26 \\
\hline $\mathrm{Ca}$ & 5.79 & 5.54 & 5.10 \\
\hline \multicolumn{4}{|c|}{$(\mathrm{mg} / \mathrm{g} \mathrm{DM})$} \\
\hline InsP-6 $^{4}$ & 1.87 & 1.92 & 1.84 \\
\hline InsP-5 $^{4}$ & 0.44 & 0.45 & 0.42 \\
\hline InsP-4 $^{4}$ & 0.02 & 0.03 & 0.02 \\
\hline InsP-1/2/3 $^{4}$ & $\dagger$ & $\dagger$ & $\dagger$ \\
\hline \multicolumn{5}{|c|}{$(\mathrm{MJ} / \mathrm{kg} \mathrm{DM})$} & 11.46 \\
\hline $\mathrm{ME}^{5}$ & 11.49 & 11.21 & 7.02 \\
\hline $\mathrm{NEL}^{7}$ & 7.05 & 6.82 & \\
\hline
\end{tabular}

${ }^{\dagger}$ out of level of quantification, while the lowest standard $(0.5-3.2 \mathrm{mg} / \mathrm{g} \mathrm{DM})$ is defined as the 'level of quantification`

${ }^{1}$ diet with supplemented mineral $\mathrm{P}$

2 diet with native $\mathrm{P}$ content

${ }^{3}$ diet with native $\mathrm{P}$ content, added with phytase

${ }^{4}$ Inositol Phosphorus

${ }^{5}$ calculated according to GfE (2001) by using the digestibility's from the AIA-Method

The concentrates used in the diets of group P+MIN and P-MIN (concentrate 1 and concentrate 2) showed no phytase activity, while concentrate 3 ( $\mathrm{P}+\mathrm{PHY}$ group) showed a phytase activity of $5859 \pm 15 \mathrm{FTU} / \mathrm{kg}$.

\subsection{General Performance}

The feed intake of the dairy cows during the sampling period is presented in e.g. Table 3. TMR intake amounted on average $21.6 \mathrm{~kg} \mathrm{DM} / \mathrm{d}$ for all groups. No differences were observed in TMR intake across the treatments. The mean $\mathrm{P}$ concentration of the concentrate was 5.95, 4.49 and $4.37 \mathrm{~g} / \mathrm{kg}$ DM in group P+MIN, P-MIN and P+PHY, respectively. Group P+PHY showed the highest CP intake (3.35 kg/d) and P-MIN the highest intake of EE, ADF and NDF.

Table 3. Mean feed and nutrient intakes during the sampling period (LS means \pm standard error)

\begin{tabular}{|l|l|l|l|c|}
\hline & $\begin{array}{l}\text { Group } \\
\mathrm{P}+\mathrm{MIN}^{1}\end{array}$ & $\begin{array}{l}\text { Group } \\
\mathrm{P}^{-\mathrm{MIN}^{2}}\end{array}$ & $\begin{array}{l}\text { Group } \\
\mathrm{P}+\mathrm{PHY}^{3}\end{array}$ & $P$-value \\
\hline Animals/group & 8 & 8 & 8 & \\
\hline
\end{tabular}




\begin{tabular}{|l|l|l|l|l|}
\hline TMR $(\mathrm{kg} \mathrm{DM} / \mathrm{d})$ & $21.3 \pm 1.03$ & $21.3 \pm 1.03$ & $22.1 \pm 1.03$ & 0.413 \\
\hline Crude protein $(\mathrm{kg} / \mathrm{d})$ & $2.92 \pm 0.07^{\mathrm{a}}$ & $3.21 \pm 0.07^{\mathrm{b}}$ & $3.35 \pm 0.07^{\mathrm{b}}$ & $<0.001$ \\
\hline Ether extract $(\mathrm{kg} / \mathrm{d})$ & $0.51 \pm 0.01^{\mathrm{a}}$ & $0.75 \pm 0.01^{\mathrm{c}}$ & $0.62 \pm 0.01^{\mathrm{b}}$ & $<0.001$ \\
\hline ADF $(\mathrm{kg} / \mathrm{d})$ & $3.50 \pm 0.08^{\mathrm{a}}$ & $3.79 \pm 0.08^{\mathrm{b}}$ & $3.80 \pm 0.08^{\mathrm{b}}$ & 0.012 \\
\hline NDF $(\mathrm{kg} / \mathrm{d})$ & $7.38 \pm 0.17^{\mathrm{a}}$ & $8.00 \pm 0.17^{\mathrm{b}}$ & $7.80 \pm 0.17^{\mathrm{b}}$ & 0.021 \\
\hline
\end{tabular}

a, b, c Different letters in one row show significant differences $(\mathrm{P}<0.05)$

${ }^{1}$ diet with supplemented mineral $\mathrm{P}$

2 diet with native $\mathrm{P}$ content

${ }^{3}$ diet with native $\mathrm{P}$ content, added with phytase

The milk performance data showed no differences between the treatments e.g. Table 4. Average milk yield amounted to $26.8 \pm 1.9 \mathrm{~kg} / \mathrm{d}$, fat corrected milk $(\mathrm{FCM})$ to $27.4 \pm 1.9 \mathrm{~kg} / \mathrm{d}$. The mean milk fat content was $4.15 \pm 0.23 \%$, the protein content $3.46 \pm 0.1 \%$ and the lactose content $4.72 \pm 0.1 \%$. The averaged SCC was $175 \pm 55 \mathrm{tsd} / \mathrm{ml}$ and the urea concentration $264 \pm 12 \mathrm{ppm}$.

Table 4. Average milk yield and milk composition as well as milk P- and Ca-concentration during the sampling period (LS means \pm standard error)

\begin{tabular}{|l|c|c|c|c|}
\hline & $\mathrm{P}^{\mathrm{MIN}}{ }^{1}$ & $\mathrm{P}_{-\mathrm{MIN}^{2}}$ & $\mathrm{P}+\mathrm{PHY}^{3}$ & $P$-value \\
\hline Animals/group & 8 & 8 & 8 & \\
\hline Milk yield (kg/d) & $27.1 \pm 1.9$ & $26.8 \pm 1.9$ & $26.6 \pm 1.9$ & 0.984 \\
\hline Fat Corrected Milk (kg/d) & $27.5 \pm 1.9$ & $27.4 \pm 1.9$ & $27.3 \pm 1.9$ & 0.997 \\
\hline Fat content (\%) & $4.08 \pm 0.23$ & $4.22 \pm 0.23$ & $4.15 \pm 0.23$ & 0.914 \\
\hline Protein content (\%) & $3.39 \pm 0.08$ & $3.44 \pm 0.08$ & $3.54 \pm 0.08$ & 0.436 \\
\hline Lactose content (\%) & $4.64 \pm 0.09$ & $4.70 \pm 0.09$ & $4.81 \pm 0.09$ & 0.398 \\
\hline Somatic cell count (tsd/ml) & $146 \pm 55$ & $278 \pm 54$ & $100 \pm 55$ & 0.079 \\
\hline Urea (ppm) & $245 \pm 12$ & $275 \pm 12$ & $272 \pm 12$ & 0.171 \\
\hline Phosphorus (g /kg DM) & $0.90 \pm 0.03$ & $0.92 \pm 0.03$ & $0.91 \pm 0.03$ & 0.885 \\
\hline Calcium (g/kg DM) & $1.2 \pm 0.03$ & $1.2 \pm 0.03$ & $1.1 \pm 0.03$ & 0.794 \\
\hline
\end{tabular}

${ }^{1}$ diet with supplemented mineral $\mathrm{P}$

2 diet with native $\mathrm{P}$ content

${ }^{3}$ diet with native $\mathrm{P}$ content, added with phytase

The P-concentration in milk was on average 7.1 $\pm 0.2 \mathrm{~g} \mathrm{P} / \mathrm{kg} \mathrm{DM}$ and did not differ between groups. The Ca-concentration was on average $9.0 \pm 0.1 \mathrm{~g} / \mathrm{kg} \mathrm{DM}$.

\subsection{Digestibility and Balances of $P$ and $C a$}

The mean daily $\mathrm{P}$-and Ca-intake is listed in e.g. Table 5. P-intake differed between the groups without P-supplementation and the P-supplemented group and was 74 and $72 \mathrm{~g} \mathrm{P} / \mathrm{d}$ for group $\mathrm{P}-\mathrm{MIN}$ and $\mathrm{P}+\mathrm{PHY}$ compared with $85 \mathrm{~g} \mathrm{P} / \mathrm{d}$ for group $\mathrm{P}+\mathrm{MIN}$. The ratio between $\mathrm{Ca}-$ and P-intake was 1.6:1 for group P-MIN, 1.5:1 for group P+MIN and 1.6:1 for group P+PHY. The ratio differed significantly $(\mathrm{P}<0.001)$, whereby the animals fed the highest amount of $\mathrm{P}$ (Group $\mathrm{P}+\mathrm{MIN})$ showed the lowest value. 


\section{Ml Macrothink}

There was no influence of treatment on the excretion of $\mathrm{P}$ and $\mathrm{Ca}$ with milk, faeces and urine during the sampling period e.g. Table 5.

Table 5. Mean P- and Ca-intakes and excretion with milk, faeces and urine as well as P- and Ca-balance during the sampling period (LS means \pm standard error)

\begin{tabular}{|c|c|c|c|c|}
\hline & $\mathrm{P}+\mathrm{MIN}^{1}$ & $\mathrm{P}_{-\mathrm{MIN}^{2}}$ & $\mathrm{P}+\mathrm{PHY}^{3}$ & $P$-value \\
\hline Animals/group & 8 & 8 & 8 & \\
\hline \multicolumn{5}{|l|}{ Intake $(\mathrm{g} / \mathrm{d})$} \\
\hline Phosphorus & $84.9 \pm 4^{\mathrm{a}}$ & $73.7 \pm 4^{b}$ & $71.8 \pm 4^{b}$ & 0.039 \\
\hline Calcium & $123.5 \pm 6$ & $117.9 \pm 6$ & $112.6 \pm 6$ & 0.414 \\
\hline \multicolumn{5}{|c|}{ Excretion with faeces $(\mathrm{g} / \mathrm{d})$} \\
\hline Phosphorus & $34.5 \pm 3$ & $32.4 \pm 3$ & $31.0 \pm 3$ & 0.636 \\
\hline Calcium & $64.3 \pm 6$ & $78.8 \pm 6$ & $74.9 \pm 6$ & 0.221 \\
\hline \multicolumn{5}{|c|}{ Excretion with urine $(\mathrm{g} / \mathrm{d})$} \\
\hline Phosphorus & $0.57 \pm 0.1$ & $0.60 \pm 0.1$ & $0.36 \pm 0.1$ & 0.196 \\
\hline Calcium & $0.57 \pm 0.1$ & $0.29 \pm 0.1$ & $0.49 \pm 0.1$ & 0.186 \\
\hline \multicolumn{5}{|c|}{ Excretion with milk (g/d) } \\
\hline Phosphorus & $24.3 \pm 2$ & $24.5 \pm 2$ & $24.0 \pm 2$ & 0.971 \\
\hline Calcium & $31.3 \pm 2$ & $31.0 \pm 2$ & $30.0 \pm 2$ & 0.907 \\
\hline \multicolumn{5}{|l|}{ Balance $(\mathrm{g} / \mathrm{d})$} \\
\hline Phosphorus & $26.4 \pm 2^{a}$ & $16.2 \pm 2^{b}$ & $16.5 \pm 2^{b}$ & 0.004 \\
\hline Calcium & $27.3 \pm 3^{\mathrm{a}}$ & $7.8 \pm 3^{b}$ & $7.2 \pm 3^{b}$ & $<0.001$ \\
\hline \multicolumn{5}{|c|}{ Total tract digestibility (\%) } \\
\hline Phosphorus & $59.8 \pm 2.4$ & $56.1 \pm 2.4$ & $56.8 \pm 2.4$ & 0.519 \\
\hline Calcium & $48.6 \pm 2.8^{\mathrm{a}}$ & $33.9 \pm 2.9^{b}$ & $33.5 \pm 2.8^{b}$ & 0.001 \\
\hline
\end{tabular}

a, b Different letters in one row show significant differences $(\mathrm{P}<0.05)$

${ }^{1}$ diet with supplemented mineral $\mathrm{P}$

P-concentration in faeces for the different groups was averagely $6.7 \pm 0.6 \mathrm{~g} / \mathrm{kg} \mathrm{DM}$. Ca-concentration in faeces of group $\mathrm{P}+\mathrm{MIN}$ was lower $(13.6 \pm 1 \mathrm{~g} / \mathrm{kg} \mathrm{DM} ; \mathrm{P}=0.019)$ compared to both other groups (15.1 and $15.4 \mathrm{~g} / \mathrm{kg}$ DM for P-MIN and P+PHY). Total tract apparent digestibility of $\mathrm{P}$ and $\mathrm{Ca}$ estimated by the AIA method is shown in e.g. Table 5. The $\mathrm{P}$-digestibility coefficients (on average $57.6 \%$ ) did not differ among treatments $(\mathrm{P}=0.519)$. In contrast, the digestibility of $\mathrm{Ca}$ was higher for $\mathrm{P}+\mathrm{MIN}(\mathrm{P}=0.001)$ and showed no differences between P-MIN and P+PHY.

There was no influence of treatment on the excretion of $\mathrm{P}$ and $\mathrm{Ca}$ with milk, faeces and urine during the sampling period. The $\mathrm{P}+\mathrm{MIN}$ group retained more $\mathrm{P}$ and $\mathrm{Ca}$ with the consequence 


\section{Macrothink}

that nearly $80 \%$ of the additional $\mathrm{P}$ in group $\mathrm{P}+\mathrm{MIN}$ were retained.

\subsection{Blood Analysis}

The course of the $\mathrm{Ca}$ and $\mathrm{P}$-concentrations in blood serum during the sampling period did not show differences between the treatments.

There was a slight decrease in serum P-concentration during the sampling period e.g. Figure 1. All feeding groups started with a higher P-concentration in blood serum than they finished with at sampling day 6. Group P-MIN had a P-concentration of $1.8 \mathrm{mmol} / \mathrm{L}$ at sampling day 1 , while it closed at sampling day 6 at a concentration of $1.5 \mathrm{mmol} / \mathrm{L}$. Both other groups started with 1.7 $\mathrm{mmol} / \mathrm{L}$, the group $\mathrm{P}+\mathrm{MIN}$ ended with the same concentration as the control group P-MIN, while the phytase group $\mathrm{P}+\mathrm{PHY}$ signs up the lowest concentration with $1.35 \mathrm{mmol} / \mathrm{L}$.

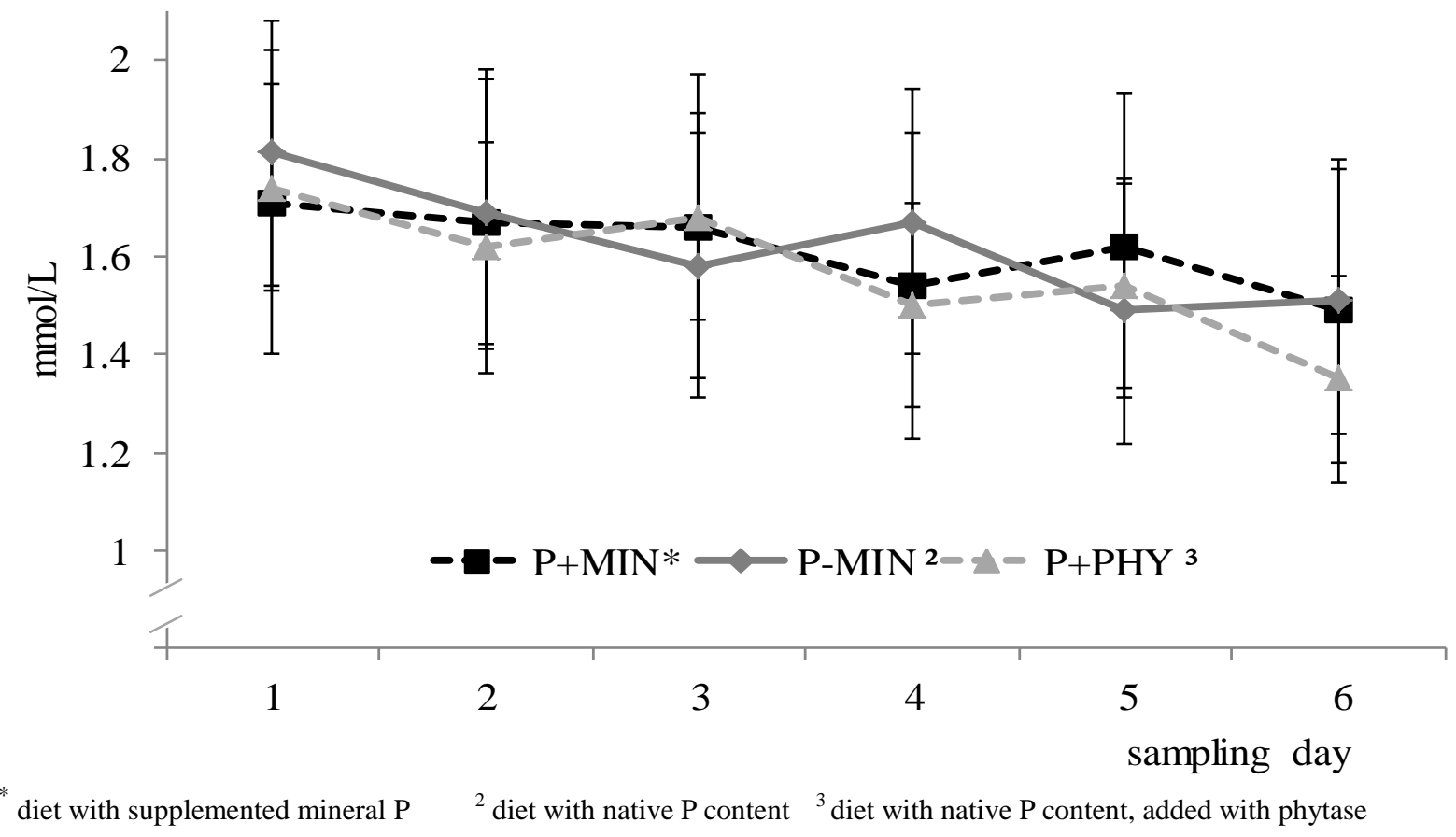

Figure 1. P-concentration ( $\mathrm{mmol} / \mathrm{L})$ in blood during the sampling period $(\mathrm{n}=8)$

The concentration of $\mathrm{Ca}$ in blood serum is constant in all groups e.g. Figure 2. 


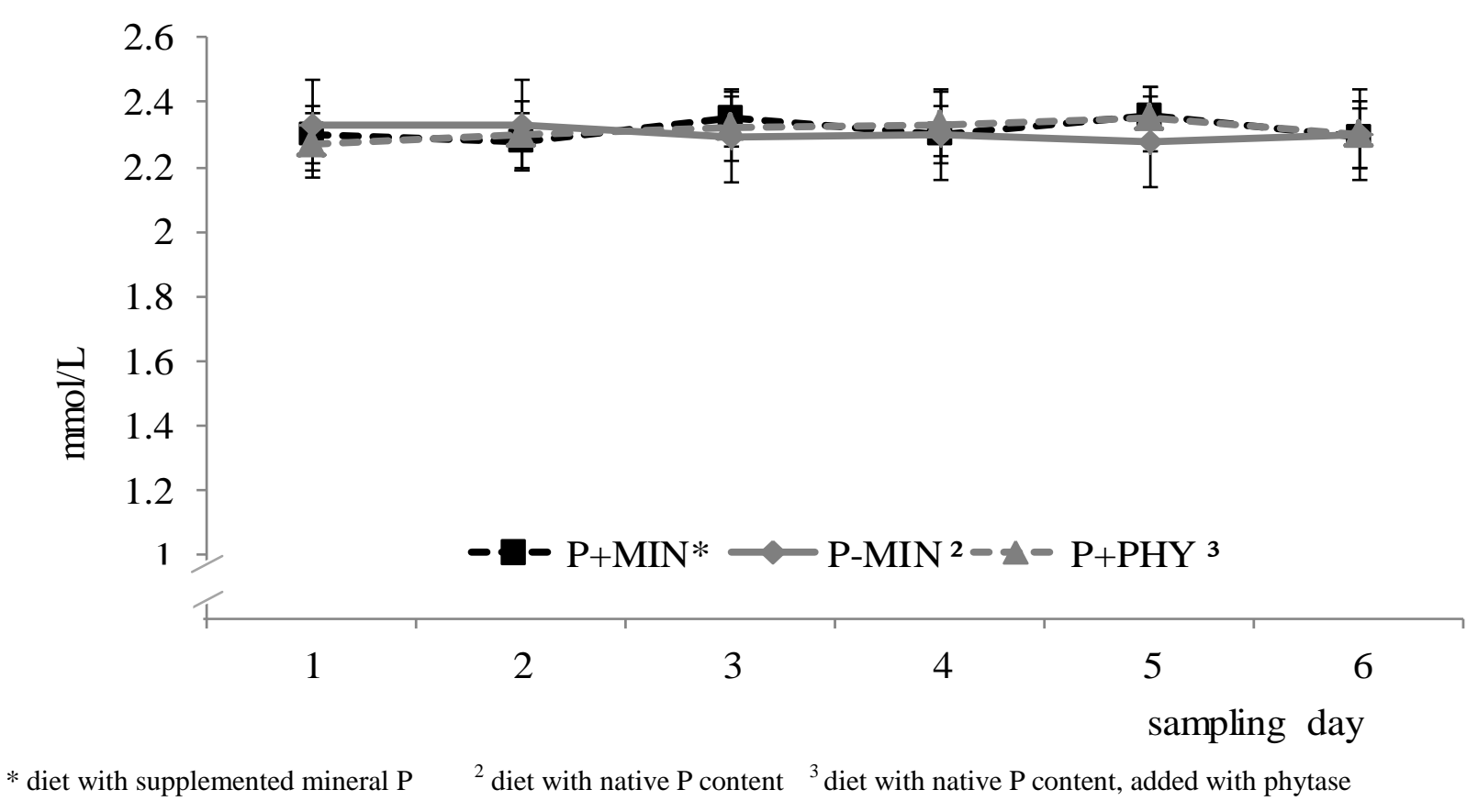

Figure 2. Ca-concentration $(\mathrm{mmol} / \mathrm{L})$ in blood serum during the sampling period $(\mathrm{n}=8)$

Results of blood serum analysis for total protein (71.4-78.4 g/L), AST (65.4-78.9 IU/L), GGT (28.5-33.1 IU/L), GLDH (16.1-33.1 IU/L), cholesterine (4.3-4.5 mmol/L), FFA (105-166 $\mu \mathrm{mol} / \mathrm{L})$ and $\beta$-hydroxybutyrate (BHB) $(0.3-0.6 \mathrm{mmol} / \mathrm{L})$ from the beginning and the end of the experiment are within the reference values given by Kraft and Dürr (2005). The values of glucose (3.7-3.9 $\mathrm{mmol} / \mathrm{L})$, Urea $(3.2-5.9 \mathrm{mmol} / \mathrm{L})$ and creatinine $(\mu \mathrm{mol} / \mathrm{L})$ are near the reference values. No treatment effects were observed in the blood parameters at the beginning of the adaptation period and at the end of the sampling period.

\section{Discussion}

P-requirements for milk synthesis represent the largest proportion of the total $\mathrm{P}$ amount required by lactating dairy cows. If the milk performance rises, an increasing amount of $\mathrm{P}$ must be fed, but a P-concentration higher than $4 \mathrm{~g} / \mathrm{kg} \mathrm{DM}$ is, even at high performance levels, not necessary (Brintrup et al., 1993; Valk et al., 2002; Wu et al., 2000). The P-concentration of the $\mathrm{P}+\mathrm{MIN}$ diet was calculated to represent the commonly used diet for a dairy cow with a milk yield of about $30 \mathrm{~kg} / \mathrm{d}$. Therefore mineral $\mathrm{P}$ was supplied to this diet. The TMR of group P-MIN (3.46 g P/kg DM) was intended to include the native $\mathrm{P}$ of the feedstuffs, only. Thus this group has a 20 percent lower P-concentration than the diet of the $\mathrm{P}+\mathrm{MIN}$ group $(3.98 \mathrm{~g} \mathrm{P} / \mathrm{kg}$ $\mathrm{DM})$. The animals of group P+PHY received a concentrate similar to group P-MIN (3.26 g $\mathrm{P} / \mathrm{kg} \mathrm{DM})$, but supplemented with an experimental phytase.

The feed ingredients including corn silage, corn, soybean meal and dried sugar beet pulp contributed to the comparatively low dietary $\mathrm{P}$ as compared with other diets commonly used for dairy cows. The P-concentration of the corn silage was on average $2.72 \mathrm{~g} / \mathrm{kg} \mathrm{DM}$ and the 
mean P-concentration of the concentrate was $4.49 \mathrm{~g} / \mathrm{kg}$ DM. With $59-70$ percent phytate $\mathrm{P}$ (InsP-6/5/4/3/2/1) in total $\mathrm{P}$, the part of phytate $\mathrm{P}$ is higher than half of the total $\mathrm{P}$ in the diets and should be available for hydrolysis catalyzed by phytase.

Milk yield was unaffected by the dietary treatments. A similar result was reported by Kincaid et al. (2005) and by Yang et al. (1997) who found no differences in milk yield, when the P-content of TMR was $0.45 \%$.

Commonly, a P-concentration in milk of about $0.9 \mathrm{~g} / \mathrm{kg}$ milk is indicated in the literature (Brintrup et al., 1993; Knowlton \& Herbein, 2002; Pfeffer et al., 2005). Nevertheless, there are variations between experiments with values ranging from 0.7 to $1.1 \mathrm{~g} / \mathrm{kg}$ milk (Pfeffer \& Hristov, 2005). Reference values for $\mathrm{P}$ in milk $(\mathrm{g} / \mathrm{kg})$ of lactating Holstein cows over the complete lactation are between 0.85-0.94 g P/kg milk (Brintrup et al., 1993; Valk et al., 2002; Wu et al., 2000) and for early- and mid-lactation between 0.68 and $0.89 \mathrm{~g} \mathrm{P} / \mathrm{kg}$ milk (Knowlton $\&$ Herbein, 2002; Knowlton et al., 2001). In the present trial the values ranged between 0.88 and $0.91 \mathrm{~g} \mathrm{P} / \mathrm{kg}$ milk and 1.09 and $1.12 \mathrm{~g} \mathrm{Ca} / \mathrm{kg}$ milk. They are similar to the mean P-and Ca-concentration of 0.9 and $1.1 \mathrm{~g} / \mathrm{kg}$ milk given by Pfeffer et al. (2005a). The present results show and Pfeffer and Hristov (2005) concluded that the P-intake has no influence on the P-excretion with milk. It should be still recognized, that the current study contradicts experiments conducted by Coates and Ternouth (1992) with cattle.

With regard to the P-recommendations, it is conspicuous that the excretion of $\mathrm{P}$ with milk is assumed between 0.9 and 2.0 g P per kg milk (Beyer et al., 2004; CVB, 2005; GfE, 2001; INRA, 2002; NRC, 2001; Schlegel, 2011). Bearing these recommendations in mind, the values out of the present study are just below values given by the GfE (2001) even though the P-intake was comparatively high. This confirms the statement that P-intake with feed has no influence on P-concentration in milk and supports the previous studies of Wu et al. (2001). Considering the actual study, it would be possible to decrease the value for P-concentration in milk to $0.9 \mathrm{~g}$ per kg milk, like other recommendations already did (INRA, 2002; NRC, 2001). Moreover the actual results shows that the presumption of $2 \mathrm{~g}$ P per $\mathrm{kg}$ milk (Beyer et al., 2004) is overestimated. The reduction of P-concentration in milk in the recommendations of Schlegel (2011), CVB (2005), Beyer et al. (2004) and GfE (2001) from 2 resp. $1 \mathrm{~g}$ to $0.9 \mathrm{~g}$ P per kg milk could help to reduce the faecal P-concentrations without it would be harmful for the health of the cows.

Overfeeding of dietary $\mathrm{P}$ is common in the diets for dairy cows. $\mathrm{P}$ is often fed to dairy cattle 20 to 40 percent in excess of published requirements (Knowlton et al., 2004; Sink et al., 2000). P fed in excess of the requirements is excreted and a reduction of overfeeding could be a powerful tool to reduce the P-concentration in faeces (Knowlton et al., 2004). Pfeffer and Hristov (2005) observed correlations between faecal P-excretion and DMI indicating that per kg DMI 0.88 g P was inevitable lost in faeces of goats. Similar to Pfeffer and Hristov (2005) other authors found the direct line between P-intake and P-excretion in dairy cows (Knowlton \& Herbein, 2002; Knowlton et al., 2001; Knowlton et al., 2004; Morse et al., 1992; Wu et al., 2001; Wu et al., 2000). In the current study P-excretion with faeces was similar to a study conducted by Coates and Ternouth (1992). In this study, faecal P-excretion was unaffected by 
either the dietary P-intake or the added exogenous phytase fed to cows. Dvorakova (1998) determined the $\mathrm{pH}$-value, temperature, moisture and time of incubation in the rumen and ileum as relevant factors affecting the digestibility of $\mathrm{P}$. Consequently, caused by the high feed intakes in high-producing dairy cows, ruminal passage-rates are rapid, which limits the time for hydrolysis in the rumen (Garikipati \& Kincaid, 2004). In the current study, this assumption cannot be proved, thus there was no lower P-excretion with faeces of the cows fed the phytase supplementation.

The total tract apparent digestibility of $\mathrm{P}$ and $\mathrm{Ca}$ is described differently in the literature. While Wu et al. (2000) presents interactions between the P-intake and P-digestibility, Silva Filho et al. (1992) determined missing interactions between these parameters. In accordance with Silva Filho et al. (1992) who studied the effect of dietary P-concentrations on P-metabolism in Bos indicus, in the current study no effect of P-intake on P-digestibility was observed. In contrast, the Ca-digestibility which showed a significantly influenced by P-intake. The group with the highest $\mathrm{P}$-intake $(\mathrm{P}+\mathrm{MIN})$ was able to digest about 15 percentage points more Ca compared with the other groups.

$\mathrm{P}$ and $\mathrm{Ca}$ retention for all dietary treatments was positive. However, the $\mathrm{P}+\mathrm{MIN}$ group showed a higher $\mathrm{P}-(\mathrm{P}=0.004)$ and $\mathrm{Ca}$-balance $(\mathrm{P}<0.001)$ compared with both other groups. This means that more $\mathrm{P}$ and $\mathrm{Ca}$ were retained in the body of the animals than in the $\mathrm{P}-\mathrm{MIN}$ and $\mathrm{P}+\mathrm{PHY}$ groups. In the current study, a higher mineral $\mathrm{P}$ intake enabled the cows to retain more $\mathrm{P}$ and $\mathrm{Ca}$. Valk et al. (2002) found comparable results for lactating dairy cows even at a lower P-intake level. P and Ca could be stored in bones, teeth, soft tissues and blood. Because there were no differences in the P-concentration in blood e.g. Figure 1, it can be assumed that bones or soft tissues would have shown differences between the groups.

When comparing the retention of the $\mathrm{P}$, it can be noticed that the group $\mathrm{P}+\mathrm{MIN}$ had the highest P-retention. This higher value can be explained by the used P-supplement. The group P+MIN received inorganic $\mathrm{P}$ supplements while the diets of both other groups contained only native $\mathrm{P}$. The comparison between the group P-MIN and P+MIN showed that there is a difference of $11 \mathrm{~g} / \mathrm{d}$ in the P-intake and of $10 \mathrm{~g} / \mathrm{d}$ in the P-balance. $91 \%$ of the supplemented $\mathrm{P}$ in group $\mathrm{P}+\mathrm{MIN}$ were utilized. The comparison of group $\mathrm{P}+\mathrm{PHY}$ and $\mathrm{P}+\mathrm{MIN}$ showed that the intake of the groups differed about $13 \mathrm{~g} / \mathrm{d}$ and the balance about $9 \mathrm{~g} / \mathrm{d}$. Consequently $69 \%$ of the supplemented $\mathrm{P}$ in group $\mathrm{P}+\mathrm{MIN}$ were utilized.

The concentrations of $\mathrm{P}$ and $\mathrm{Ca}$ in serum were not affected either by the exogenous phytase or by the different P-intake. According to literature data Hadzimusic (2011) summarized that the reference values of $\mathrm{P}$ in blood of cows are between between 1.4 and $2.5 \mathrm{mmol} / \mathrm{L}$ (Merck, 2008). The range of reference values for $\mathrm{Ca}$ in blood serum of lactating cows is between 2.1 to 3.1 mmol/L (Hadzimusic, 2011; Jovanovic et al., 1997; Kaneko, 2008; Kraft \& Dürr, 2005; Merck, 2008; Radostits et al., 2000). The values of $\mathrm{Ca}$ and $\mathrm{P}$ in this experiment are below or respectively near the minimum level of the reference values e.g. Figures 1 and 2.

Morse et al. (1992), Knowlton et al. (2001) and Wu et al. (2001) investigated that there is a relationship between the intake and output of minerals. The present analytic values for P-and 


\section{$\Lambda$ Macrothink}

Journal of Biology and Life Science ISSN 2157-6076 2013, Vol. 4, No. 2

Ca-balance support this statement that the P-intake has an influence on the P-balance. The desired positive effect of phytase with regard to a better P-digestibility did not occur. In accordance with Kiarie and Nyachoti (2010) and under the conditions examined the supply of phytase could not reduce the excretion of non-digestible P. Brask-Pedersen et al. (2013) figured out, that a higher supply of exogenous phytase increases the ruminal degradation of inositol $\mathrm{P}_{6}\left(\mathrm{InsP}_{6}\right)$. The supply of phytase increases the ruminal phytase activity. The phytase concentration in the diets of the current study are nearly similar to the high concentrated group of the study by Brask-Pedersen et al. (2013). However the actual study shows no phytase activity in the rumen. Against this back ground, the question arises if a higher amount of phytase supplementation could have resulted in differences between the treatments. In previous studies ruminal and total-tract degradations of $\mathrm{InsP}_{6}$ were higher when exogenous phytase was added to the TMR. Degradation of InsP $_{6}$ occurred mainly in the rumen as the content of $\mathrm{InsP}_{6}$ was lower in the duodenum samples in animals fed phytase (Brask-Pedersen et al., 2013). Bearing this in mind, it could be advantageous to examine the $\mathrm{pH}$-value and temperature in the rumen to prove that the phytase can work efficiently. Dvorakova (1998) determined that the rated range of $\mathrm{pH}$ is 2.5 or 5.5 for Aspergillus niger phytase, while Brask-Pedersen et al. (2013) mentioned that the optimum $\mathrm{pH}$ for the phytase used in their study was 5 to 5.5. The lower $\mathrm{pH}$-optimum of the phytase can constitute a reason that in the current study the phytase has no influence on the P-retention, in so far that the $\mathrm{pH}$-value of the rumen of a dairy cow is higher than 5.5. Under conditions as presented here, it makes more sense to determine the lower limits for the P-supply of the different ruminants and different performances than to use the tested phytase in this quantity. Furthermore research is needed to determine the effect of incubation time, passage rate, $\mathrm{pH}$-value and phytase activity in the rumen and duodenal chyme.

\section{Conclusions}

Dietary phytase supplementation in dairy cows fed different amounts of $\mathrm{P}$ showed no effect on P-excretion with faeces and urine as well as the P-balance. The results of the experiment indicate that the addition of the tested phytase had no influence on the P-excretion in milk. The reduction of $\mathrm{P}$ concentration in milk in the recommendations from 2 resp. $1 \mathrm{~g}$ to $0.09 \mathrm{~g}$ per $\mathrm{kg}$ milk could help to reduce the faecal P-concentration without it would be harmful for the health of the cows.

\section{Acknowledgements}

The authors would like to thank the DSM Nutritional Products Ltd for financial support. Furthermore, the assistance of the co-workers of the Institute of Animal Nutrition and the Experimental Station of the Friedrich-Loeffler-Institute (FLI) in Braunschweig, Germany in performing the experiment and analysis is gratefully acknowledged.

\section{References}

Brask-Pedersen, D. N., Glitso, L. V., Skov, L. K., Lund, P., \& Sehested, J. (2011). Effect of exogenous phytase on feed inositol phosphate hydrolysis in an in vitro rumen fluid buffer system. Journal of Dairy Science. 94(2). 951-959. http://dx.doi.org/10.3168/jds.2010-3504 


\section{$\Lambda$ Macrothink}

Brask-Pedersen, D. N., Glitso, L. V., Skov, L. K., Lund, P., \& Sehested, J. (2013). Effect of exogenous phytase on degradation of inositol phosphate in dairy cows. Journal of Dairy Science. 96(3). 1691-1700. http://dx.doi.org/10.3168/jds.2011-5278

Brejnholt, S. M., Dionisio, G., Glitsoe, V., Skov, L. K., \& Brinch-Pedersen, H. (2011). The degradation of phytate by microbial and wheat phytases is dependent on the phytate matrix and the phytase origin. Journal of the Science of Food and Agriculture. 91(8). 1398-1405. http://dx.doi.org/10.1002/jsfa.4324

Brintrup, R., Mooren, T., Meyer, U., Spiekers, H., \& Pfeffer, E. (1993). Effects of 2 Levels of Phosphorus Intake on Performance and Fecal Phosphorus Excretion of Dairy-Cows. Journal of Animal Physiology and Animal Nutrition-Zeitschrift Fur Tierphysiologie Tierernahrung Und Futtermittelkunde. 69(1). 29-36. http://dx.doi.org/10.1111/j.1439-0396.1993.tb00787.x

Coates, D. B., \& Ternouth, J. H. (1992). Phosphorus Kinetics of Cattle Grazing Tropical Pastures and Implications for the Estimation of Their Phosphorus Requirements. Journal of Agricultural Science. 119. 401-409. http://dx.doi.org/10.1017/S0021859600012247

CVB. (2005). Centraal Veevoederbureau. Voedernormen landbouwhuisdieren en voederwaarde veevoeders. .

Dvorakova, J. (1998). Phytase: Sources, preparation and exploitation. Folia Microbiologica. 43(4). 323-338. http://dx.doi.org/10.1007/BF02818571

Eeckhout, W., \& De Paepe, M. (1994). Total Phosphorus, Phytate-Phosphorus and Phytase Activity in Plant Feedstuffs. Animal Feed Science and Technology. 47(1-2). 19-29. http://dx.doi.org/10.1016/0377-8401(94)90156-2

Engelen, A. J., Vanderheeft, F. C., Randsdorp, P. H. G., \& Smit, E. L. C. (1994). Simple and Rapid-Determination of Phytase Activity. Journal of Aoac International. 77(3). 760-764.

Garikipati, D., \& Kincaid, R. (2004). Effect of exogenous phytase on phosphorus digestibility in dairy cows and calves. Journal of Animal Science. 82. 118-118.

GfE, (2001). Gesellschaft für Ernährungsphysiologie. Empfehlungen zur Energie- und Nährstoffversorgung der Milchkühe und Aufzuchtrinder.

Ggg Kraft, W., \& Dürr, U. M., (2005). Klinische Labordiagnostik in der Tiermedizin. Stuttgart/New York.

Gizzi, G., Thyregod, P., von Holst, C., Bertin, G., Vogel, K., Faurschou-Isaksen, M., Betz, R., Murphy, R., \& Andersen, B. B. (2008). Determination of phytase activity in feed: Interlaboratory study. Journal of Aoac International. 91(2). 259-267.

Godoy, S., \& Meschy, F. (1999). Utilisation of phytic P by rumen bacteria in a semi-continuous culture system (rusitec). South African Journal of Science. 29. 148-149.

Guyton, A. D., McKinney, J. M., \& Knowlton, K. F. (2003). The effect of steam-flaked or dry ground corn and supplemental phytic acid on phosphorus partitioning and ruminal 
phytase activity in lactating cows. Journal of Dairy Science. 86(12). 3972-3982. http://dx.doi.org/10.3168/jds.S0022-0302(03)74008-9

Hadzimusic, N. J. K. (2011). Values of Calcium, Phosphorus and Magnesium Concentrations in Blood Plasma of Cows in Dependence on the Reproductive Cycle and Season. Journal of the Faculty of Veterinary Medicine, Istanbul University 38. 1-8.

Hhh Beyer, M., Chudy, A., Hoffmann, L., Jentsch, W., Laube, W., Nehring, K., \& Schiemann, R., (2004). Rostocker Futterbewertungssystem. Rostock, Germany: Jentsch, W., A. Chudy and M. Beyer.p.392..

INRA, (2002). Institut National de la Recherche Agronomique. Tables de l'alimentation des ruminants (Vol. 2): Institut National de la Recherche Agronomique.

Jovanovic, J. M., Rajic, I., Pesterac, V., Crcev, D., \& Cokrevski, S. (1997). Parametri krvi visoko steonih I tek oteljenih krava hranjenih obrocima razlicitog sastava. Veterinarski Glasnik. 51. 231-244.

Kaneko, J. J., (2008). Carbohydrate Metabolism and Its Diseases (Vol. 6.th edition). New York: Academic Press.p.64..

Kiarie, E., \& Nyachoti, C. M., (2010). Bioavailibilty of Calcium and Phosphorus in Feedstuffs for Farm animals. United Kingdom: CABI publishing, Oxfordshire.p.76-93..

Kienzle, E., (1991). Ernährung und Urolithiasis bei Haussäugetieren (Vol. 19).p.157-200..

Kincaid, R. L., \& Rodehutscord, M., (2005). Phosphorus Metabolism in the rumen. United Kingdom: CABI Publishing, Cambridge.p.189-191..

Kincaid, R. L., Garikipati, D. K., Nennich, T. D., \& Harrison, J. H. (2005). Effect of grain source and exogenous phytase on phosphorus digestibility in dairy cows. Journal of Dairy Science. 88(8). 2893-2902. http://dx.doi.org/10.3168/jds.S0022-0302(05)72970-2

Knowlton, K. F., \& Herbein, J. H. (2002). Phosphorus partitioning during early lactation in dairy cows fed diets varying in phosphorus content. Journal of Dairy Science. 85(5). 1227-1236. http://dx.doi.org/10.3168/jds.S0022-0302(02)74186-6

Knowlton, K. F., Herbein, J. H., Meister-Weisbarth, M. A., \& Wark, W. A. (2001). Nitrogen and phosphorus partitioning in lactating Holstein cows fed different sources of dietary protein and phosphorus. Journal of Dairy Science. 84(5). 1210-1217. http://dx.doi.org/10.3168/jds.S0022-0302(01)74582-1

Knowlton, K. F., Radcliffe, J. S., Novak, C. L., \& Emmerson, D. A. (2004). Animal management to reduce phosphorus losses to the environment. Journal of Animal Science. 82. 173-195.

Knowlton, K. F., Taylor, M. S., Hill, S. R., Cobb, C., \& Wilson, K. F. (2007). Manure nutrient excretion by lactating cows fed exogenous phytase and cellulase. Journal of Dairy Science. 90(9). 4356-4360. http://dx.doi.org/10.3168/jds.2006-879 


\section{$\triangle$ Macrothink}

Journal of Biology and Life Science ISSN 2157-6076 2013, Vol. 4, No. 2

Mccarthy, J. F., Aherne, F. X., \& Okai, D. B. (1974). Use of Hcl Insoluble Ash as an Index Material for Determining Apparent Digestibility with Pigs. Canadian Journal of Animal Science. 54(1). 107-109. http://dx.doi.org/10.4141/cjas74-016

Merck. (2008). In Co., M. (Ed.), Merck veterinary manual (Vol. 8th ed.). Inc Whitehause Station, NJ, USA..

Morse, D., Head, H. H., \& Wilcox, C. J. (1992). Disappearance of Phosphorus in Phytate from Concentrates Invitro and from Rations Fed to Lactating Dairy-Cows. Journal of Dairy Science. 75(7). 1979-1986. http://dx.doi.org/10.3168/jds.S0022-0302(92)77957-0

NRC. (2001). National Research Council, Nutrient requirements of dairy cattle. 7th revised edition ed. National Academy of Science, Washington D.C.

Pfeffer, E., \& Hristov, A. N., (2005). Nitrogen and $P$ nutrition of cattle, reducing the environmental Impact of cattle operations. United Kingdom: CABI Publishing, Cambridge.p.208-219. http://dx.doi.org/10.1079/9780851990132.0000

Pfeffer, E., Beede, D. K., \& Valk, H., (2005). Phosphorus Metabolism in Ruminants and Requirements of Cattle. United Kingdom: CABI publishing, Cambridge.p.195-231..

Radostits, O. M., Blood, D. C., \& Gay, C. C., (2000). A textbook of the diseases of cattle, sheep, goats and horses (Vol. 8th edition). London.

Reid, R. L., M.C. Franklin. (1947). The utilization of phytate phosphorus by sheep. Aust Vet Journal. 23. 136-140. http://dx.doi.org/10.1111/j.1751-0813.1947.tb14728.x

Rodehutscord, M. (2008). Approaches for saving limited phosphate resources. Archiv Fur Tierzucht-Archives of Animal Breeding. 51. 39-48.

Schlegel, P., ALP. (2011). Phosphorempfehlung für die Milchkuh. Paper presented at the ALP Tagung 2011. .

Selle, P. H., Walker, A. R., \& Bryden, W. L. (2003). Total and phytate-phosphorus contents and phytase activity of Australian-sourced feed ingredients for pigs and poultry. Australian Journal of Experimental Agriculture. 43(5). 475-479. http://dx.doi.org/10.1071/EA02155

Silva Filho, J. C., Lopes, H. O. S., Meirelles, C. F., Vitti, D. M. S. S., \& Abdalla, A. L. (1992). Absorcao real de fosforo do fosfato bicalcico, fosfato monoamonio, superfosfato triplo e do fosfato de ureia em bovinos. . Pesquisa Agropecuaria Brasileira. 35. 1861-1865. http://dx.doi.org/10.1590/S0100-204X2000000900019

Sink, S. E., Knowlton, K. F., \& Herbein, J. H. (2000). Economic and environmental implications of overfeeding phosphorus on Virginia Dairy Farms. Journal of Animal Science. 78(Suppl.2)(4).

Sunvold, G. D., \& Cochran, R. C. (1991). Technical Note-Evaluation of Acid Detergent Lignin, Alkaline Peroxide Lignin, Acid Insoluble Ash, and Indigestible Acid Detergent Fiber as Internal Markers for Prediction of Alfalfa, Bromegrass, and Prairie Hay Digestibility by 
Beef Steers. Journal of Animal Science. 69(12). 4951-4955.

Valk, H., Sebek, L. B. J., \& Beynen, A. C. (2002). Influence of phosphorus intake on excretion and blood plasma and saliva concentrations of phosphorus in dairy cows. Journal of Dairy Science. 85(10). 2642-2649. http://dx.doi.org/10.3168/jds.S0022-0302(02)74349-X

VDLUFA. (1997). Die chemische Untersuchung von Futtermitteln. Ergänzungslieferungen von 1983, 1988, 1992, 1997, 2004, 2006, 2007. VDLUFA-Methodenbuch. 3.

Wu, Z., Satter, L. D., \& Sojo, R. (2000). Milk production, reproductive performance, and fecal excretion of phosphorus by dairy cows fed three amounts of phosphorus. Journal of Dairy Science. 83(5). 1028-1041. http://dx.doi.org/10.3168/jds.S0022-0302(00)74967-8

Wu, Z., Satter, L. D., Blohowiak, A. J., Stauffacher, R. H., \& Wilson, J. H. (2001). Milk production, estimated phosphorus excretion, and bone characteristics of dairy cows fed different amounts of phosphorus for two or three years. Journal of Dairy Science. 84(7). 1738-1748. http://dx.doi.org/10.3168/jds.S0022-0302(01)74609-7

Wünsche, J., Borgmann, E., Henning, U., Kreienbring, F., \& Bock, H. D. (1984). Application of the $\mathrm{HCl}$-insoluble ash as an indicator for the determination of nutrient including amino-acid digestibility at the end of the small intestine and the whole digestive-tract of pigs. Archive of Animal Nutrition. 34. 817-831.

Yang, W. Z., Beauchemin, K. A., Farr, B. I., \& Rode, L. M. (1997). Comparison of barley, hull-less barley, and corn in the concentrate of dairy cows. Journal of Dairy Science. 80(11). 2885-2895. http://dx.doi.org/10.3168/jds.S0022-0302(97)76253-2

Yanke, L. J., Bae, H. D., Selinger, L. B., \& Cheng, K. J. (1998). Phytase activity of anaerobic ruminal bacteria. Microbiology-Uk. $144 . \quad 1565-1573$. http://dx.doi.org/10.1099/00221287-144-6-1565

Zimmermann, B., Lantzsch, H. J., Mosenthin, R., Schoner, F. J., Biesalski, H. K., \& Drochner, W. (2002). Comparative evaluation of the efficacy of cereal and microbial phytases in growing pigs fed diets with marginal phosphorus supply. Journal of the Science of Food and Agriculture. 82(11). 1298-1304. http://dx.doi.org/10.1002/jsfa.1190

\section{Copyright Disclaimer}

Copyright reserved by the author(s).

This article is an open-access article distributed under the terms and conditions of the Creative Commons Attribution license (http://creativecommons.org/licenses/by/3.0/). 